A N N A L E S

UNIVERSITATIS MARIAE CURIE-SKŁODOWSKA

LUBLIN - POLONIA

VOL. LXX, z. 1

SECTIO B

2015

Katedra Geotechniki

Zachodniopomorski Uniwersytet Technologiczny w Szczecinie

e-mail: seulcyprian@wp.pl; bednarek@zut.edu.pl

CYPRIAN SEUL, ROMAN BEDNAREK

\title{
Utwory zastoiskowe doliny Iny między Witkowem a Tychowem koło Stargardu Szczecińskiego
}

Glacilacustrine deposits of Ina Valley between Witkowo and Tychowo near Stargard Szczeciński

Słowa kluczowe: Dolina Iny, osady zastoiskowe, sondowania CPTU, analiza uziarnienia, datowania TL

Key words: Ina Valley, glacilacustrine deposits, CPTU tests, grain-size, TL dating

\section{WSTĘP}

W pracy przedstawiono wykorzystanie wyników badań geotechnicznych uzupełnionych o badania litologiczne osadów budujących dolinę Iny między Tychowem a Witkowem koło Stargardu. Długa rynna glacjalna została wypełniona osadami mułkowo-ilastymi w czasie wytapiania się lądolodu z fazy pomorskiej zlodowacenia północnopolskiego oraz osadami mineralnymi i organicznymi w holocenie.

Podczas uzupełniających badań geologicznych związanych z projektem nitki gazociągu Świnoujście - Lwówek Wielkopolski wykonano 20 otworów badawczych w poprzek doliny o głębokości od $6 \mathrm{~m}$ do ponad $30 \mathrm{~m}$ w części środkowej doliny.

W związku z tym, że w środkowej części doliny natrafiono na znaczną miąższość osadów organicznych i zastoiskowych glin pylastych, wykonano sondowania CPTU oraz pobrano próbki osadów. Oprócz standardowych badań geotechnicznych dla wybranych 2 próbek określono wiek TL.

Wyniki badań potwierdzają istnienie zbiornika sedymentacyjnego wypełniającego dolinę w późnym plejstocenie (gliny pylaste), w którym spokojną sedy- 
mentację w zbiorniku przerywały zmienne warunki sedymentacyjne. W holocenie osadzały się gytie, namuły oraz torfy.

\section{WSTĘP}

Rzeka Ina wypływa z jeziora Ińskiego znajdującego się na zapleczu szerokiej strefy marginalnej z fazy Pomorskiej zlodowacenia Wisły. Od miejscowości Recz Ina skręca na zachód i wraz z dopływem Stobnica do Stargardu Szczecińskiego płynie doliną o szerokości od 1,5 do ponad $2 \mathrm{~km}$. W środkowym odcinku na południe od Tychowa płynie w uregulowanym korycie o szerokości około $10 \mathrm{~m}$ i głębokości 1-2 m. Ta część doliny należy do terasy zalewowej, która w okresach roztopów wiosennych jest często podtapiana. Po obu stronach rzeki zostały wybudowane wały przeciwpowodziowe. Dolina Iny w tym rejonie wypełniona jest siecią kanałów melioracyjnych (np. Kanał Rzepliński), a przepływy reguluje system hydrotechniczny. Szeroka dolina Iny ciągnie się przez $30 \mathrm{~km}$ od Recza do Stargardu Szczecińskiego, gdzie dopływa Mała Ina oraz Krąpiel. W Stargardzie Szczecińskim dolina Iny zmienia kierunek na północ i znacznie się zwęża do szerokości poniżej $0,5 \mathrm{~km}$, rozcinając wysoczyznę morenową (Karczewski 1988). Obecna środkowa część doliny Iny została utworzona w czasie wytapiania się lądolodu z fazy pomorskiej zlodowacenia północnopolskiego oraz przemodelowana w holocenie (Ryc. 1). Ukształtowanie podłoża przedczwartorzędowego północno-zachodniej Polski przyczyniło się do formowania układu rynien glacjalnych (Kowalska 1960) wpływających na tworzenie się kształtu dolnego odcinka dorzecza Odry. Badania Dyjora (1991) dolin kopalnych Polski zachodniej w okresach interglacjalnych wskazują na funkcjonowanie doliny kopalnej w tym miejscu przez znaczną część plejstocenu, która była odpreparowywana w okresach interglacjalnych. Powstanie i rozwój tej części doliny wiąże się z częściowym wypełnianiem rynny glacjalnej, która została wykorzystana przez wody roztopowe w czasie deglacjacji związanej z fazą pomorską (Sylwestrzak 1978; Sochan i in. 2004; Mojski 2005).

Podczas uzupełniających badań geologiczno-inżynierskich związanych z budową gazociągu przez dolinę Iny wykonano szereg otworów wiertniczych, które pozwoliły na przybliżenie przekroju poprzecznego szerokiej doliny Iny w rejonie Witkowa oraz na przebieg i charakter osadów pochodzenia zastoiskowego, dochodzących w sąsiedztwie obecnego koryta Iny do głębokości ponad $30 \mathrm{~m}$.

\section{CEL I METODYKA BADAŃ}

Celem pracy jest analiza odtworzenia warunków sedymentacyjnych utworów zastoiskowych wypełniających dolinę Iny między Tychowem a Witkowem. 


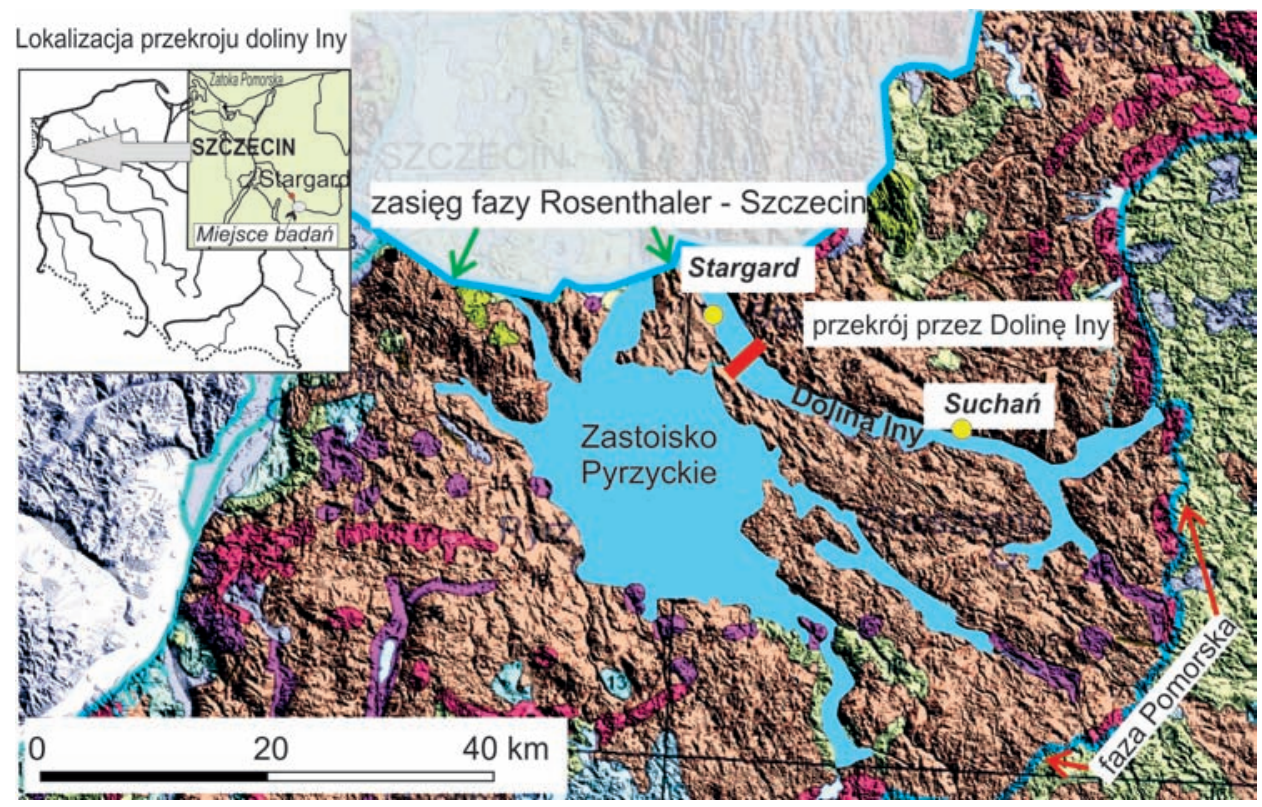

Ryc. 1. Lokalizacja doliny Iny na tle Mapy Geologicznej (Nita i in. 2006) z zaznaczeniem fazy Rosenthaler - Szczecin (Börner 2004)

Fig. 1. Location of Ina valley against the Geological Map background (Nita i in. 2006), with phase Rosenthaler - Szczecin marked (Börner 2004)

Podczas badań uzupełniających do projektu budowy nitki gazociągu Świnoujście - Lwówek Wielkopolski na odcinku Tychowo-Witkowo zostało wykonanych 20 otworów wiertniczych w przekroju poprzecznym doliny w odległości od 50 do $200 \mathrm{~m}$ o głębokości od kilku metrów do prawie $40 \mathrm{~m}$. W trakcie badań terenowych pobierano próbki do standardowych badań geotechnicznych; wilgotność, granice konsystencji, określenie części organicznych metodą utleniania (próbki z dużą zawartością węglanów) i prażenia (torfy i namuły organiczne). Po wstępnym rozpoznaniu przekroju doliny rzecznej dodatkowo w dwóch miejscach wykonano badania wytrzymałości podłoża sondą wciskaną CPTU do głębokości $30 \mathrm{~m}$ oraz $\mathrm{w}$ otworze przy sondzie pobrano próby (w tym rdzeniowe) między innymi w przedziale 14-19 m p.p.t. Dla tych próbek, oprócz podstawowych badań geotechnicznych wykonano analizę uziarnienia osadów metodą dyfraktometrii laserowej w aparacie Masterzizer 2000 oraz dla wybranych dwóch próbek osadów pobranych z głębokości 16,0-16,2 m i 19,0-19,2 m zostały wykonane badania wieku luminescencyjną metodą TL w laboratorium Uniwersytetu Gdańskiego (próbki nr UG - 6992 i 6993). Metodyka określania wieku TL jest opisana przez Federowicza (2006). 
Badania wytrzymałościowe osadów wykonano tylko za pomocą sondy CPTU. Interpretacja wyników została wykonana zgodnie z klasyfikacją Robertsona z 1990 roku z modyfikacją dostosowaną do warunków polskich (Młynarek $i$ in. 1997). Badania sondą CPTU są szeroko stosowane w praktyce rozpoznawania gruntów (Lunne i in. 1997). Badanie podłoża w miejscu występowania, w stanie naturalnym pozwala na ocenę wielu parametrów geotechnicznych, dlatego jest obecnie tak chętnie stosowane (Młynarek i in. 2007; Wierzbicki i in. 2008). Przykładem wykorzystania sondy CPTU do interpretacji warunków sedymentacyjnych są miedzy innymi badania Paluszkiewicza (Paluszkiewicz i in. 2010).

Na podstawie wykonanych badań można rozróżnić granice między gruntami organicznymi a zastoiskowymi glinami pylastymi. Analizując wyniki oporu pod podstawą stożka sondy oraz oporu na pobocznicy, można stwierdzić, że osady występujące pod torfami i namułami charakteryzują się bardzo podobnymi parametrami. Wnioskować można, że warunki tworzenia struktury gruntów były bardzo podobne. Bardzo niskie wartości parametru $(q c)$ uzyskane podczas sondowania wskazują na słabą konsolidację osadów zastoiskowych. Może to być związane ze znacznym ciśnieniem wód naporowych występujących w piaskach wodnolodowcowych znajdujących się pod zastoiskowymi utworami zastoiskowymi. Jednakże na wykresie oporu pod podstawą stożka zarejestrowano w przelocie 16-20 m p.p.t. zmiany oporu stożka z jednoczesnym zmniejszeniem ciśnienia wody w porach $\mathrm{w}$ glinach pylastych. Wskazuje to na zmienne warunki sedymentacyjne osadu (najprawdopodobniej przewarstwienia drobnopiaszczyste) serii glin pylastych (Ryc. 2).

Potwierdzają to również badania uziarnienia utworów zastoiskowych. Rozkłady uziarnienia w przelocie $14,0-16,5 \mathrm{~m}$ są bardzo podobne i wskazują na depozycję osadu w warunkach spokojnej sedymentacji, natomiast zalegające poniżej osady w przelocie 18,0-19,4 m charakteryzują się odmiennymi rozkładami uziarnienia, a szczególnie próbka pobrana z głębokości 19,0-19,4 m, która charakteryzuje się rozkładem bimodalnym, wskazując na inne warunki sedymentacyjne (Ryc. 3). Wskaźniki Folka, Warda (Mz - przeciętna wielkość ziarna, $\mathrm{s}_{1}$ - wysortowanie, $\mathrm{SK}_{1}$ - skośność oraz $\mathrm{K}_{\mathrm{G}}$ - spłaszczenie) (Racinowski i in. 2001) glin pylastych pobranych z głębokości $19 \mathrm{~m}$ oraz zalegających powyżej potwierdzają zmiany sedymentacyjne, jakie zachodziły w trakcie depozycji osadów. W przelocie 17-19 m zmiany warunków sedymentacyjnych widoczne są również na wykresie sondy CPTU (wahania wartości oporu pod stożkiem - qc) (Ryc. 2).

Wiek osadu datowany metodą TL próbki z głębokości 19,0 m wynosi 14,4 \pm 2,0 tys. lat, natomiast wiek próbki z głębokości 16,0 m datowany jest na 11,9 $\pm 1,7$ tys. lat. Różnice w rozkładach uziarnienia w powiązaniu z wynikami datowania osadów wskazują na zmiany warunków sedymentacyjnych podczas wypełniania funkcjonującego wówczas zastoiska. 


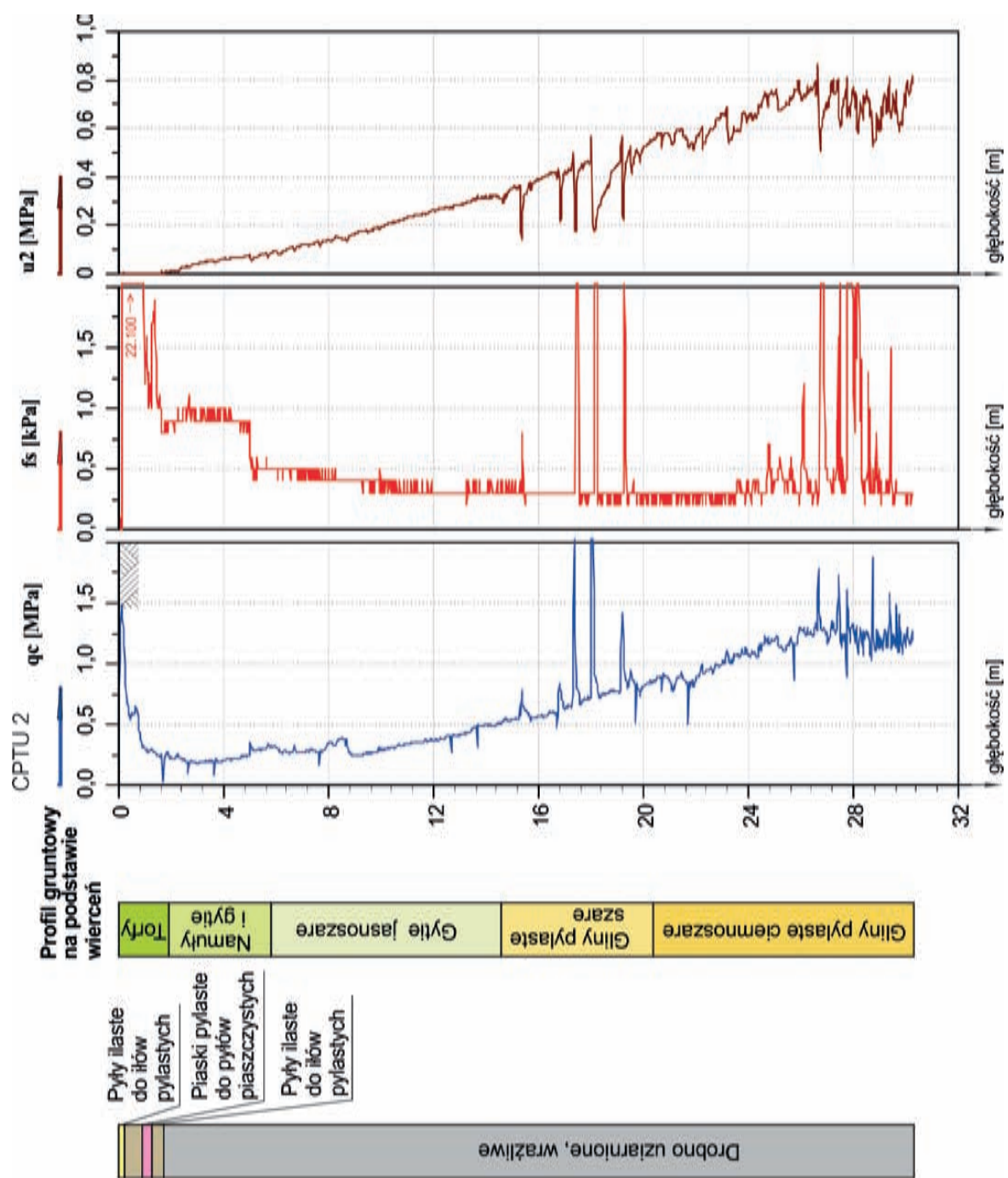

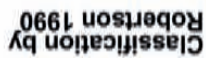

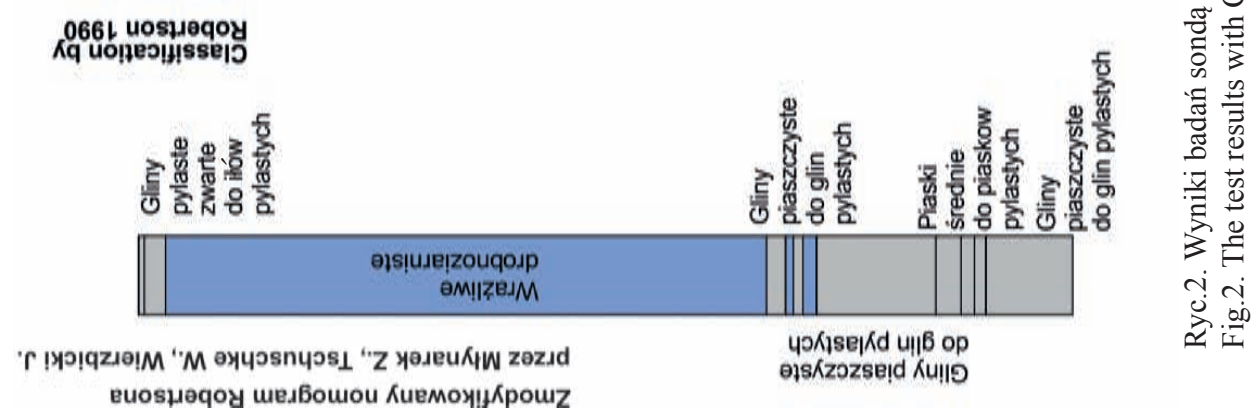




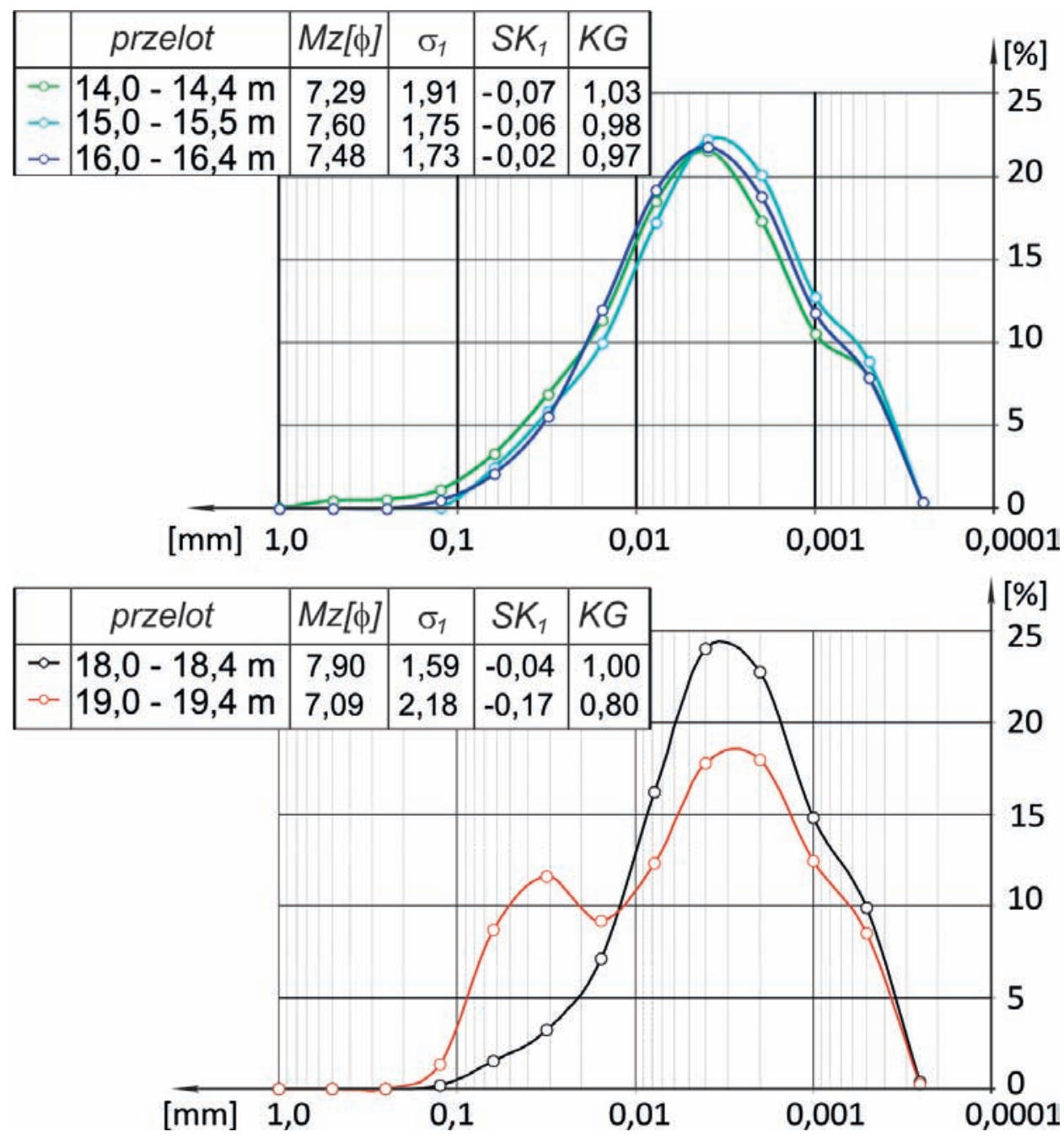

Ryc. 3. Rozkłady uziarnienia badanych próbek osadów

Fig. 3. Grain size distributions of sediment samples tested

\section{ROZWÓJ DOLINY INY W REJONIE WITKOWA}

Omawiany odcinek doliny Iny stanowi fragment rynny glacjalnej, w której w spągu zaznaczają się piaski wodnolodowcowe pochodzące prawdopodobnie z faz starszych zlodowacenia Wisły. Nawiercono je w środkowej części doliny na głębokości 35-40 m p.p.t. Na obrzeżach doliny powyżej znajdują się gliny morenowe z fazy leszczyńskiej lub poznańskiej (Wiśniewski i in. 2004). W następnych okresach zostały w środkowej części wyerodowane i ich miejsce zostało wypeł- 
nione ilasto-pylastymi osadami zastoiskowymi. Gliny morenowe fazy starszej od pomorskiej zostały przykryte materiałem wodnolodowcowym i lodowcowym z faz młodszych zlodowacenia Wisły, najprawdopodobniej z fazy pomorskiej (Sochan i in. 2004). W środkowej części przekroju doliny od głębokości ponad $30 \mathrm{~m}$ na osadach wodnolodowcowych zalegają osady mułkowo-ilaste wykształcone jako gliny pylaste. Są one ciemnoszare, przechodzące w stropie do szarych. Strop tych utworów znajduje się na głębokości około $14 \mathrm{~m}$ p.p.t. Brak jest wyraźnej granicy przejścia mułków ilastych (gliny pylaste) w gytie. Na mułkach zastoiskowych zalegają jasnoszare gytie węglanowe, które przykryte są namułami organicznymi z brązowymi gytiami. Granica między namułami a gytiami jest już wyraźniejsza i widoczna na profilu sondy CPTU (Ryc. 2). Na tych osadach wytworzyła się warstwa torfów niskich o miąższości od 3 do $4 \mathrm{~m}$ (Ryc. 4). Powierzchnia terenu to łąki na glebach torfowych, rozcięte kanałami i rowami melioracyjnymi.

Osady wodnolodowcowe w dnie doliny wiąże się ze osadami stadiału środkowego zlodowacenia Wisły, a gliny zwałowe występujące na krawędziach doliny i rozdzielające je osady piaszczyste ze stadiałem głównym fazy leszczyńsko-poznańskiej (Sochan i in. 2004). Osady zastoiskowe wypełniające dolinę Iny rozwinęły się podczas wytapiania pokrywy lodowej z fazy pomorskiej zlodowacenia północnopolskiego. Osady mułkowo-ilaste wskazują na istnienie zastoiska na obszarze doliny. Charakter tych osadów nawiązuje do osadów „Zastoiska Pyrzyckiego", które znajduje się kilka kilometrów na zachód od tego fragmentu doliny Iny. Zastoisko Pyrzyckie ma bardziej złożony charakter, gdyż na podstawie badań związanych z arkuszem Szczegółowej Mapy Geologicznej Dolice (Sochan i in. 2004) oraz Stare Czarnowo (Ruszała 1995) osady zastoiskowe datowane są od okresu wczesnego vistulianu do fazy pomorskiej zlodowacenia północnopolskiego. Najmłodsze osady „Zastoiska” wiąże się z subfazą szczecińską (Karczewski 1968). Znajdujące się niedaleko osady mułkowe (Zastoisko Pyrzyckie) w części stropowej (odsłonięcie w Okunicy) datowane były na wiek TL około 15 tys. lat (Sochan i in. 2004). Może to wskazywać na podobny czas tworzenia się osadów oraz na podobne warunki sedymentacyjne. Jednakże osady mułkowe „Zastoiska Pyrzyckiego” są barwy jasnożółtej i żółtej, a mułki w dolinie Iny wykształcone jako gliny pylaste z tego samego okresu (podobne daty TL) są barwy szarej. Wskazywać może to na odmienne warunki sedymentacyjne i postsedymentacyjne.

Datowane osady pobrane w środkowej części badanego profilu, mułki ilaste z głębokości $19 \mathrm{~m}$, potwierdzają depozycję z okresu początku deglacjacji fazy pomorskiej (wiek TL 14,4 \pm 2,0 tys. lat), a mułki ilaste z głębokości 16 m wska-

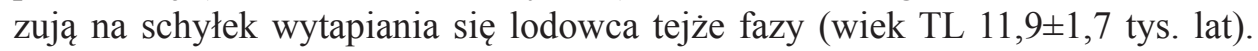
Gliny pylaste znajdujące się na głębokości $19 \mathrm{~m}$ prawdopodobnie można wiązać z depozycją osadów w czasie postoju czoła lądolodu, który blokował odpływ wód w kierunku północno-zachodnim w fazie szczecińskiej (Karczewski 1968) 


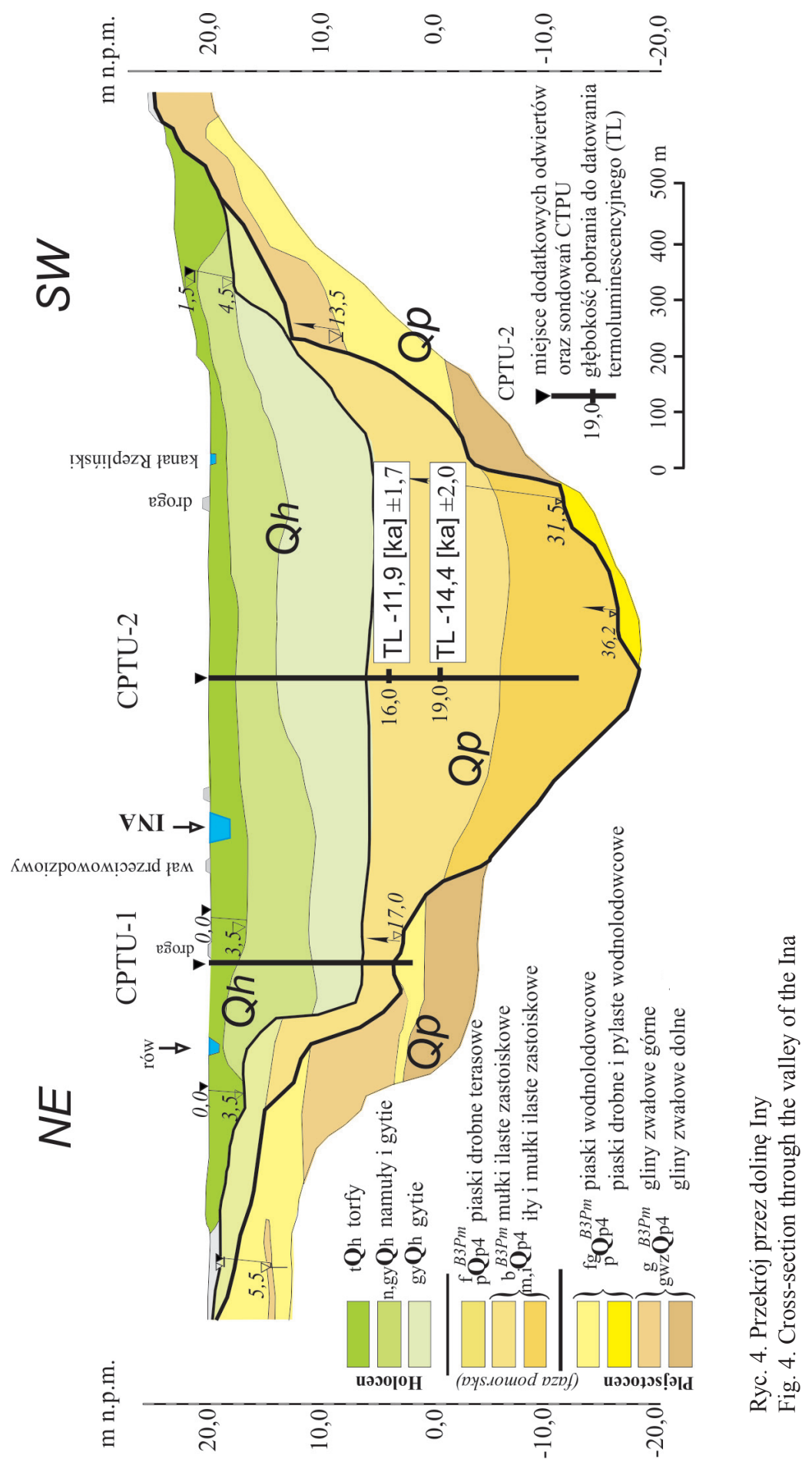


zwaną również fazą (subfazą) Rosenthal - Szczecin (Börner 2004, Piotrowski i in. 2012). Rozkłady uziarnienia osadów mułkowo-ilastych na głębokości $19 \mathrm{~m}$ p.p.t. (typowy rozkład dwumodalny) wyraźnie różnią się od zalegających na nich podobnych mułków pylasto-ilastych znajdujących się na głębokości $18 \mathrm{~m}$ p.p.t. $\mathrm{Na}$ tych osadach od głębokości około $14 \mathrm{~m}$ deponowane były już w przełomie plejstocenu i holocenu gytie węglanowe, na których osadzały się namuły i torfy. Znaczenie zwężająca się dolina Iny w Stargardzie Szczecińskim wypełniona jest osadami organicznymi i cienką warstwą drobnych piasków, które zalegają na szarych glinach morenowych. Strop glin morenowych znajduje się na rzędnej około 10-12 m n.p.m. Strop osadów lodowcowych w omawianym przekroju doliny Iny koło Witkowa znajduje się na głębokości około $35 \mathrm{~m}$ (odpowiada to rzędnej -20 m n.p.m.), strop glin pylastych przechodzących w gytie znajduje się na głębokości około $14 \mathrm{~m}$ (odpowiada to rzędnej około $10 \mathrm{~m}$ n.p.m.). Wskazuje to wyraźnie na występowanie bariery, jaką stanowiły gliny morenowe znajdujące się w dnie doliny Iny w Stargardzie Szczecińskim (Piotrowski i in. 2008). Bariera ta umożliwiała funkcjonowanie podłużnego zbiornika wypełniającego rynnę glacjalną od miejscowości Recz poprzez Suchań aż do Stargardu Szczecińskiego (ok. $30 \mathrm{~km}$ ) w późnym plejstocenie i na początku holocenu. Zbiornik wypełniający się osadami mułkowo-ilastymi (gliny pylaste) w holocenie został przykryty gytiami, namułami organicznymi oraz torfami.

Brak możliwości pobrania próbek do badań z głębokości 30 m nie daje możliwości określenia czasu powstania zbiornika i rozpoczęcia depozycji osadów.

\section{PODSUMOWANIE}

Na podstawie uzupełniających badań do projektu gazociągu przez dolinę Iny koło Stargardu zauważa się, że w rejonie Tychowa istnieje szeroka dolina wypełniona osadami mineralnymi i zastoiskowymi osadami o miąższości ponad $30 \mathrm{~m}$. Na podstawie analiz pobranych próbek rozdzielono torfy, namuły oraz gytie i osady mineralne. Na podstawie analiz uziarnienia osady mineralne zaliczono do osadów mułkowo-ilastych. Rozkłady dwumodalne osadów mułkowych potwierdzają zmienne warunki sedymentacyjne (Ryc. 3), co jest również widoczne na wykresie oporu stożka sondy CTPU (Ryc. 2). Sondowania prowadzone sondą CTPU wykazały bardzo słabą nośność gruntów organicznych oraz zalegających niżej mineralnych osadów mułkowo-ilastych, które są przewarstwione cienkimi laminami piasków. Wstępne informacje uzyskane podczas badań w tym rejonie mogą być przydatne do szerszego projektu badań paleogeograficznych rozwoju Doliny Iny w plejstocenie. 


\section{LITERATURA}

Börner A., 2004. Stratigraphical division of Quaternary in Mecklemburg-Vorpommern, [w:] XI Konferencja Stratygrafia Plejstocenu Polski (red. A. Ber i in.). Supraśl, 30.08 - 3.09. 2004. Państwowy Instytut Geologiczny, Warszawa, 26-28.

Dyjor S., 1991. Wpływ ewolucji paleogeograficznej na rozwój zlodowaceń w Polsce Zachodniej, [w:] Geneza, litologia i stratygrafia utworów czwartorzędowych, A. Kostrzewski (red.). Wyd. Nauk. UAM Poznań, seria Geografia 50, 419-433.

Federowicz S., 2006. Metodyczne aspektu luminescencyjnego określania wieku osadów neoplejstoceńskich Europy Środkowej. Wyd. Uniwersytetu Gdańskiego, ss. 156.

Karczewski A., 1968. Wpływ recesji lobu Odry na powstanie i rozwój sieci dolinnej Pojezierza Myśliborskiego i Niziny Szczecińskiej. Pr. Kom. Geogr.-Geol. PTPN, 8(3), 3-105.

Karczewski A., 1998. Geomorfologia. Nizina Szczecińska i pojezierze Myśliborskie. Wyd. UAM Poznań.

Kowalska A., 1960. Paleomorfologia powierzchni podplejstoceńskiej niżowej części dorzecza Odry. Prace Geograficzne PAN, 21, 75.

Lunne T., Robertson P.K., Powell J.J.M., 1997. Cone Penetration Testing in Geotechnical Practice. E\&FN Spon, London, pp. 352.

Młynarek Z., Tschuschke W., Wierzbicki J.,1997. Klasyfikacja gruntów podłoża budowlanego metoda statycznego sondowania. Geotechnika w Budownictwie i Transporcie. XI Krajowa Konferencja Mechaniki Gruntów i Fundamentowania, Gdańsk, t. 2, s. 119-126.

Młynarek Z., Wierzbicki J., 2007. Nowe możliwości i problemy interpretacyjne polowych badań gruntów. Geologos 11, 97-118.

Mojski J.E., 2005. Ziemie polskie w czwartorzędzie. Zarys morfogenetyczny. Państwowy Instytut Geologiczny. Warszawa, ss. 404.

Nita J., Chybiorz R., 2006. Mapa geologiczna Polski na tle rastrowego modelu rzeźby terenu. Uniwersytet Śląski.

Paluszkiewicz R., Paluszkiewicz R., Wierzbicki J., 2010. Zastosowanie metody statycznego sondowania w analizie genezy osadów, na przykładzie sandru Gwdy, Landform Analysis, vol. 13, 83-89.

Piotrowski A., Sochan A., Schiewe M., 2008. Szczegółowa Mapa Geologiczna Polski 1:50000, ark. Stargard Szczeciński (230). Państwowy Instytut Geologiczny. Warszawa.

Piotrowski A., Pisarska-Jamroży M., Schlaak N., Brose F, Juschus O., Przybylski B., Relisko-Rybak J., Sydor P., Krzymińska J., 2012. Wysoczyzna Pojezierza Myśliborskiego i Dolina Dolnej Odry w okolicy Cedyni, [w:] XIX Konferencja Stratygrafia Plejstocenu Polski. „Korelacja osadów plejstocenu na pograniczu polsko-niemieckim w Dolinie Dolnej Odry” (red. A. Piotrowski i in.). Cedynia, 3-7 września 2012. PIG. PIB. Warszawa, s.14-34.

Racinowski R., Szczypek T., Wach J., 2001. Prezentacja i interpretacja wyników badań uziarnienia osadów czwartorzędowych. Wyd. Uniwersytetu Śląskiego. Katowice, ss.146.

Ruszała M., 1995. Szczegółowa Mapa Geologiczna Polski wraz z objaśnieniami, 1:50000, ark. Stare Czarnowo (267). Państwowy Instytut Geologiczny. Warszawa.

Sochan A., Piotrowski A., 2004. Szczegółowa Mapa Geologiczna Polski w skali 1:50000 z objaśnieniami, ark. Dolice (268). Państwowy Instytut Geologiczny. Warszawa.

Sylwestrzak J., 1978. Rozwój sieci dolinnej na Pomorzu pod koniec plejstocenu. GTN Wydział V Nauk o Ziemi. Gdańsk, ss.161.

Wierzbicki J., Paluszkiewicz R., Paluszkiewicz R., 2008. Wytrzymałość mechaniczna osadu a jego geneza, na przykładzie wybranych utworów strefy marginalnej fazy pomorskiej zlodowacenia Wisty. Landform Analysis vol. 9, 390-393.

Wiśniowski Z., Piotrowski A., 2004. Szczegółowa Mapa Geologiczna Polski z objaśnieniami, skala 1:50000 ark. Choszczno (269). PIG Warszawa, ss. 46 


\section{SUMMARY}

Ina valley between Suchań and Stargard Szczeciński was created during a land-ice melting of Pomorska Phase (Baltic Glaciation). The valley was formed in a glacial channel in place of buried (older) river valleys.

During supplementary geological research for designed Świnoujście - Lwówek Wielkopolski gas pipeline a series of 20 test drills was carried out with a spacing of 50-100 m between them over the whole cross-section of Ina valley. The drills depth reached some $6 \mathrm{~m}$ at valley edge zone up to over $30 \mathrm{~m}$ at the central part of the valley. That allowed making detailed cross-section over the valley.

Because at the central part of the valley a significant thickness of both organic and lacustrine deposits of silty loams was found, CPTU tests were performed. In addition, samples of underlying organic deposits as well as silty ones were taken. For the samples of those deposits standard geotechnical tests were carried out, and, additionally for specified 2 samples from depth $16 \mathrm{~m}$ and $19 \mathrm{~m}$ the TL dating was done.

The results of the research confirm the presence of sediment reservoir filling the valley at late Pleistocene (silty loams) where standstill sedimentation process had been broken by turbulent sedimentation conditions. Gyttja, mud and peats (at roof) settled in Holocene. Reservoir present in Ina valley was filled with mineral deposits and was also present at the time of so-called "Zastoisko Pyrzyckie" formation. 